\title{
Physical Activity, Sensory Threshold of Sweetness, and Waist-to- Height Ratio (WHtR) in Adolescents
}

\author{
Evitha Latifah ${ }^{1 \star}$, Kusnandar ${ }^{2}$, Yulia Lanti Retno Dewi ${ }^{3}$
}

\author{
${ }^{1}$ Postgraduate Nutrition Science Program, Sebelas Maret University, Surakarta, INDONESIA \\ ${ }^{2}$ Department of Agribusiness Management, Faculty of Agriculture, Sebelas Maret University, Surakarta, INDONESIA \\ ${ }^{3}$ Department of Nutrition, Faculty of Medicine, Sebelas Maret University, Surakarta, INDONESIA \\ *Corresponding Author: evitha_latifah@yahoo.com
}

Citation: Latifah E, Kusnandar, Dewi YLR. Physical Activity, Sensory Threshold of Sweetness, and Waist-to-Height Ratio (WHtR) in Adolescents. Electron J Gen Med. 2020;17(5):em223. https://doi.org/10.29333/ejgm/7886

\begin{tabular}{|c|c|}
\hline ARTICLE INFO & ABSTRACT \\
\hline Received: 6 Nov. 2019 & e: The research objective is to reveal the correlation between physical activity and sensory thre \\
\hline Accepted: 29 Feb. 2020 & o \\
\hline
\end{tabular}

Methodology: This research was observational analytic using a cross-sectional approach. The study was conducted at State High Schools in the Districts of Jebres, Banjarsari, and Serengan in Surakarta City, which involved 140 adolescents aged 15-17 years. The physical activity data were obtained from interviews with the subjects using the Physical Activity Questionnaire for Adolescents (PAQ-A) questionnaire, and the sensory threshold of sweetness data was obtained from the identification of the subject in a sucrose solution with different concentrations. The data of the waist to height ratio were obtained by dividing the measurement value of waist circumference by a height value.

Results: The study showed that there was a significant link between the physical activity with a waist to height ratio ( $r=-0.602 ; p<0.001)$, and the sensory threshold sweetness with a waist to height ratio $(r=0.393 ; p<0.001)$.

Applications/Originality/Value: From the results of this research, it can be concluded that there is a significant relationship between physical activity and sensory threshold of sweetness with a waist to height ratio (WHtR). Adolescents with abnormal waist to height ratio (WHtR) measurements $(\geq 0.50)$ can carry out physical activity in sufficient quantities, and regulate food habits according to the needs of physical growth and development, especially limiting sugar consumption.

Keywords: abdominal obesity, adolescent, physical activity, sensory threshold of sweetness, WHtR

\section{INTRODUCTION}

Adolescents are age groups that are vulnerable to nutritional problems, so balanced nutrition is needed to accelerate growth and development of physical, psychological, neurological, and intellectual $(1,2)$. Nutrition problems that are often found in adolescents are unwanted changes in body weight, one of which is obesity due to increased muscle mass, body fat tissue, and hormonal changes $(3,4)$. The waist to height ratio (WHtR) is an anthropometric index that is more sensitive than BMI to illustrate the distribution of excess fat in the upper body and reflect the presence of harmful fat in the abdomen (abdominal obesity) (5). The use of WHtR is highly recommended for obesity screening in adolescents as the cutoff point. WHtR of $\geq 0.50 \mathrm{~cm}$ can be applied to adolescent age groups with various ethnic and gender, both male and female (6).

Obesity is one of the rapidly growing health problems among teenagers. The highest incidence rate of overweight and obesity occurs in low-and middle-income countries, with a global prevalence of overweight and obesity at the age of 5-19 years by $18 \%$ (7). The prevalence of overweight in Indonesia in adolescents aged 13-15 years increased from 2.5\% (2010) to $10.8 \%$ (2013) and $16 \%$ (2018), while the prevalence of excess weight in teenagers aged $16-18$ years also increased from $1.4 \%$ (2010) to $7.3 \%(2013)$ and $13.5 \%$ (2018) (8-10). While in the city of Surakarta, the prevalence of overweight in adolescents aged $13-15$ years was $10.9 \%$ consisting of $10.1 \%$ fat and $0.8 \%$ obesity and at the age of $16-18$ years was $12.3 \%$ consisting of $6.4 \%$ fat and $5.9 \%$ obesity (11).

Obesity in adolescents is at high risk of becoming obese in adulthood (12), potentially becoming a cause of cardiovascular and metabolic diseases $(1,13)$, and increasing mortality (14). Obesity is caused by the interaction of genetic, physiological, environmental, social, and economic factors (15), such as lifestyle changes, especially diet and physical activity (16). Dietary habits with unbalanced nutrient intake can trigger weight gain to become obese in adolescents $(17,18)$. Adolescents, with a tendency to consume food specifically, have a positive relationship with more nutritional status. Fast food consumption can increase risk by 1.23 times to become obese in adolescents aged 13-15 years with a higher percentage of body fat and an increase in body mass index by $0.08 \mathrm{~kg} / \mathrm{m}^{2}(19)$. Sugar-sweetened and soft-drink consumption 
in adolescence can also increase body mass index by $0.07-0.1$ $\mathrm{kg} / \mathrm{m}^{2}$ and the fat percentage by $4.45 \%(20,21)$.

Physical activity is the body's movements produced by skeletal muscles that require energy expenditure (22). Lack of physical activity is one of the main factors that cause overweight and obesity (23). Individuals who are less active in moving have a 2.55 times chance to become obese due to excess energy reserves in the body (24-26). Recommendations that are suggested for the prevention of being overweight become obese require more physical activity at least 45-60 minutes/day and prevention of weight gain increases again in individuals who are overweight are an encouragement to do physical activity $60-90$ minutes/day $(27,28)$.

The diversity of Indonesian society ranging from ethnicity, culture, age, and occupation has an influence on the sensitivity of sweet taste and daily sugar intake, such as, Javanese ethnic tastes tend to prefer sweet foods and drinks (29), as the Riskesdas (Basic Health Research) data (2013) which shows that the prevalence of the behavior of consuming sweet foods/drinks $\geq 1$ time a day in Central Java is $62.9 \%$; this figure is much higher than the national figure of $53.1 \%(11)$. It is undoubtedly influenced by habits that affect the sensitivity of specific tastes (30). Someone who likes and often consumes sweet foods tends to have a high threshold of sweet taste $(31,32)$, besides the condition of obesity can also affect the sensitivity of taste because there is a direct relationship between the expression of genetic variations in the taste sense and changes in the sense of taste to the sharpness in detecting taste (33-35). Given the prevalence of obesity continues to increase, especially among adolescents, this research needs to be done to determine the relationship of physical activity and sensory threshold of sweetness with the ratio of waist to height in adolescents.

\section{SUBJECT AND METHOD}

\section{Research Types and Design}

The type of this research was observational analytic with a cross-sectional approach. The study was conducted in seven senior high schools in the Banjarsari, Jebres, and Serengan Sub-districts of Surakarta. Data were collected from August till October 2019.

\section{Population and Sample}

The population in this study is adolescents aged 15-17 years who are state high school students in the Surakarta City area. The sample of this study was state high school students in the Surakarta City area. The sample size in this study was calculated using the formula (36), and based on the calculation results, it can be obtained a total sample of 140 . Sampling was done by a multi-stage random sampling method. The determination of sub-districts and schools was based on the location of state high schools located in three sub-districts (Banjarsari, Serengan, and Jebres), then the sample of adolescents in each school was selected by proportional random sampling.

The inclusion criteria in this study were teenage boys and girls attending high school in the Surakarta City area, aged 1517 years, physically and mentally healthy, not smoking, and not consuming alcohol while the exclusion criteria in this study were adolescents who were not present during the study and were menstruating.

\section{Data Collection}

\section{Physical activity}

Physical activity data collection was using the PAQ-A (Physical Activity Questionnaire for Adolescence) form with research-based categories (37). There were nine items of questions in the questionnaire related to activities carried out daily with an intensity of time was seven days before.

\section{Sweet sensory threshold}

Sensory threshold sweetness data collection was using five sucrose solutions with different concentrations based on the American Society of Testing and Materials (ASTM) (38), Sucrose solution was presented in the order of concentration from the lowest to the highest. The subjects tasted five sucrose solutions in sequence and were asked to identify samples that gave the impression of sweetness.

\section{The ratio of waist to height (WHtR)}

Data collection of the ratio of waist to height (WHtR) adolescents was through direct measurement of waist circumference and height, then divided the measurement value of waist circumference with the height value. Classification of data on the ratio of waist to height (WHtR) was based on (39) and research (6). Height measurements were carried out in an upright position as close as possible to the wall and straight ahead, and the measurement results were expressed in centimeters $(\mathrm{cm})$. Whereas, waist circumference measurements were made on the top of the iliac crest horizontally around the abdomen. The measuring tape had to stick to the skin but not to the point of pressure, and the measurement results were also expressed in centimeters $(\mathrm{cm})$.

\section{Data Analysis}

The data obtained were analyzed by using SPSS software version 22. The normality test used Kolmogorov-Smirnov, a test between physical activity and the ratio of waist to height with Pearson Product Moment correlation, while the test between the sweet taste sensory threshold and the ratio of waist to height was performed with the Spearman Rank. Pearson Product Moment Test and Spearman Rank used to determine the strength and direction of the relationship between variables.

\section{Research Ethics}

Research ethics with informed consent, anonymity, confidentiality, and ethical clearance were from the Research Ethics Commission of Sebelas Maret University, Surakarta, with numbers 142/UN27.06/KEPK/2019.

\section{RESULTS}

The research subjects were 140 adolescents aged 15-17 years, and most of them were female. Physical activity of the subjects in this study included in low physical activity with an average of 2.17. The average concentration value of the sensory threshold sweetness of $0.53 \mathrm{~g} / \mathrm{ml}$ was included in the high category. Most subjects had a normal waist to height ratio of 0.48 . The distribution of subject characteristics can be seen in Table 1. 
Table 1. Characteristics of research subjects

\begin{tabular}{|c|c|c|c|c|c|}
\hline Characteristics & $\mathbf{n}$ & $\%$ & Min Value & Max Value & Mean \pm SD \\
\hline \multicolumn{6}{|l|}{ Sex } \\
\hline Male & 68 & 48.6 & & & \\
\hline Female & 72 & 51.4 & & & \\
\hline Age (years) & & & 15 & 17 & $15.56 \pm 0.54$ \\
\hline 15 & 64 & 45.7 & & & \\
\hline 16 & 73 & 52.1 & & & \\
\hline 17 & 3 & 2.1 & & & \\
\hline Physical Activity & & & 1.191 & 3.429 & $2.17 \pm 0.62$ \\
\hline Sensory Threshold Sweetness & & & 0.06 & 0.96 & $0.53 \pm 0.32$ \\
\hline Waist-to-Height Ratio & & & 0.32 & 0.64 & $0.48 \pm 0.07$ \\
\hline
\end{tabular}

Table 2. Relationship between physical activity, sensory threshold sweetness, and waist-to-height ratio

\begin{tabular}{lcc}
\hline \multirow{2}{*}{ Variables } & \multicolumn{2}{c}{ Waist-to-Height Ratio } \\
\cline { 2 - 3 } & $\mathbf{r}$ & $\mathbf{p}$ \\
\hline Physical Activity & -0.602 & $<0.001^{\mathrm{a}}$ \\
\hline Sensory Threshold Sweetness & 0.393 & $<0.001^{\mathrm{b}}$ \\
\hline${ }^{\mathrm{a} P r o d u c t}$ Moment Correlation test & & \\
${ }^{\mathrm{b}}$ Rank Spearman test & &
\end{tabular}

Table 3. Regression analysis of physical activity, sensory threshold sweetness and waist-to-height ratio

\begin{tabular}{ccccc}
\hline Variables & B & t & p & 95\%Cl \\
\hline Physical Activity & -0.064 & -8.126 & $<0.001$ & $2.064-2.271$ \\
\hline $\begin{array}{c}\text { Sensory Threshold } \\
\text { Sweetness }\end{array}$ & 0.059 & 3.947 & $<0.001$ & $0.477-0.585$ \\
\hline Constant & 0.583 & 27.774 \\
\hline F & \multicolumn{5}{c}{51.128} \\
\hline F (sig) & $<0.001$ \\
\hline R square & 0.427 \\
\hline
\end{tabular}

The results of data analysis showed that there was a significant correlation between physical activity with the waist to height ratio (WHtR) $(p<0.001)$ with the correlation coefficient number which showed a negative relationship. Sensory threshold sweetness was also significantly related to the waist to height ratio $(p<0.001)$. The correlation coefficient showed a positive relationship between the sensory threshold sweetness and the waist to height ratio. The relationship between physical activity, sensory threshold sweetness, and waist-toheight ratio can be seen in Table 2 .

After conducting linearity analysis, normalty, and classic assumptions, it is known that there is a linear relationship between the independent variable and the dependent variable, residual value is normally distributed $(p>0.05)$, and the model is free from multicollinearity symptoms (VIF value $>10)$ and heteroscedasticity problem so that it can be continued to be analyzed by using multiple linear regression tests. Based on the result of the multiple linear regression test in Table 3, it is obtained the probability value of $F(\mathrm{sig})<0.05$, so that it can be concluded that the regression model is feasible to use. The determinant coefficient ( $R$ square) is obtained by $42.7 \%$. This is showed that the variation of waist to height ratio of $42.7 \%$ is influenced by physical activity and sensory of sweetness, while $57.3 \%$ is explained by other variables not examined. Based on the calculation of effective contributions, physical activity contributes by $32.51 \%$ affecting the waist to height ratio and sensory threshold sweetness contributes by $10.19 \%$ affecting waist to height ratio.

\section{DISCUSSION}

The taste is an important parameter that determines the acceptance of food product. Eating habit is one of the factor that affect sensory threshold related to the intensity of certain flavor found in food. The difference in eating habits is an interesting thing to study further in relation to the sensory threshold of sweetness in the Javanese tribe in Indonesia. This study was the first to be conducted to find out the relationship between sweet taste threshold and nutritional status based on the ratio of waist-height ratio (WHtR) in 15-17 years old Javanese adolescents. Indonesian especially Javanese have had a high sensory threshold for sweetness as they are accustomed to consuming sweet foods and drinks. Javanese eating habit cannot be seperated from sweet taste like the use of sugar in dishes that are a source of calories. Then, it is one of the factors associated with high energy intake. The increase in energy sourced from sweet foods is considered as one that contributes to an excess nutritional status and obesity.

\section{The Relationship Between Physical Activity and Waist to Height Ratio}

Statistical analysis showed a significant correlation between physical activity and the ratio of waist to height $(r=$ $0.602, p<0.001$ ). It is relevant to previous studies, which also reported that there was a significant inverse correlation between physical activity and the ratio of waist to height ( $p$ value $<0.001)(40)$. Physically active individuals can reduce body fat, especially in the abdominal area, thus affecting the size of the ratio of waist circumference to lower body height (41). It supports the inverse relationship between physical activity and obesity, which is explained by the low ratio of waist to height.

Physical activity plays a significant role in increasing the regulation of energy and macronutrient balance and general bodily functions (homeostasis) (42). In addition, physical activity plays an important role in preventing overweight and obesity in children and adolescents, as well as reducing the risk of obesity in adulthood (43). Puberty and adolescence are vulnerable to the development of obesity due to sexual maturation and decreased physical activity (44). Adolescents who are more physically active usually have lower body fat levels than those who are less active in moving (45). However, most adolescents in some countries are reported not to do physical activity according to recommended guidelines. Adolescents spend more time on sedentary activities such as watching television and using other electronic media (46).

Physical activity is very beneficial for adolescents. The physical activity carried out regularly in sufficient quantities can control and maintain ideal body weight and improve 
fitness and health (22). Physical activity also has psychological benefits for adolescents by providing mental health effects and better happiness so that adolescents could avoid anxiety and depression (44,47). Increasing knowledge, intelligence, creativity, productivity, ability, skills, and academic achievement are long-term positive impacts that can be obtained by adolescents from regular physical activity (48).

\section{Relationship between Sensory Threshold Sweetness and Waist to Height Ratio}

The sense of taste is one of the five senses that are active when nutrients or chemical compounds stimulated the taste receptor cells in the oral cavity (49). Taste is an important aspect that is used to determine the acceptance of food, so it plays a role in influencing one's eating behavior. The difference in the ability to detect and recognize taste is influenced by a person's daily eating habits $(30,40)$. Individuals with the habit of consuming foods with high levels of sweet taste will tend to need a high concentration of sweet taste to obtain the desired taste sensation, or the threshold of detection of sweet taste is increased (31).

The results showed that there were a significant relationship between the sensory threshold of sweetness and the waist to height ratio $(r=0.393, p<0.001)$. Relevant to the previous studies, which reported that the threshold of sweetness detection affects the size of the ratio of waist to height in children aged 7-14 years (52). Other studies have also shown that obese individuals have a higher sweet taste threshold at a concentration of $0.7 \mathrm{~g} / \mathrm{ml}$, whereas normal individuals have a sweet taste threshold at a concentration of $0.33 \mathrm{~g} / \mathrm{ml}$ (33). Significant differences in sweet taste detection threshold with Body Mass Index ( $p<0.001$ ) were also found in children aged 13-15 years in Saudi Arabia (52). A favor for sweetness and sugar-sprinkling habits also have a positive influence on increasing body mass index (31).

Individuals are born with a taste for sweetness. The sweet taste is a sign that food has calories (52). Sugary foods are consumed to provide the energy needed to increase growth and development, but an increase in energy intake, especially those sourced from sweet foods, is considered to be one that contributes to obesity (51). It is relevant to the research conducted by (53), which showed that food intake with high carbohydrate and sugar has a positive effect on obesity, which is characterized by an increase in the ratio of waist to height (WHtR).

The difference in the sweet taste threshold in children and adolescents is influenced by genetic factors that play a role in regulating the gustatory system (sense of taste). Diversity of sweet taste receptors TAS1R2, TAS1R3, and GNAT3 have been shown to affect sweet taste sensitivity $(55,56)$. Changes in leptin can also cause an increase in sweetness. Leptin is a hormone released by adipocytes (lipocytes and fat cells) which functions to regulate food intake, energy expenditure, and body weight. The sense of taste is one of the targets of leptin. Leptin selectively suppresses the response of nerves and behavior to sweet compounds without affecting other taste stimuli. Previous studies conducted on mice identified that leptin receptors in the taste buds of obese mice showed an increase of nerve response and higher behavioral preferences for sweet arousal stimuli (57). In addition, studies conducted on obese individuals undergoing a weight-loss diet program experience changes in leptin levels and lower detection rates for sweetness. It is related to the leptin receptor polymorphism
(Lys109Arg) associated with insulin and glucose metabolism (58).

Several factors caused obese individuals to have a higher taste detection threshold compared to normal individuals. First, obese individuals have lower sensory signal of sensitivity. Decreased sensitivity of this sensory signal can affect the psychology of obese individuals to increase food consumption resulting in excess energy intake, which has an impact on obesity (59). Second, there are differences in activity in the brain tissue of obese and normal individuals. The brain tissue of obese individuals shows a variety of higher activity in reaction to responses to taste stimuli. Third, the differences in CD36 expression found in the sense of taste (tongue), which are receptors related to taste sensitivity. Decreased expression of taste sensory CD36 (tongue) in obese individuals can reduce sensitivity to taste stimulation, so obese individuals must consume more food to get the desired taste sensation (60).

\section{CONCLUSION}

This study concluded that there was a significant negative correlation between physical activity and waist to height ratio. The more physically active, it will affect the size of the waist to lower height ratio. In addition, there was a significant correlation between sensory threshold sweetness and waist to height ratio.

The research result provided some recommendations for adolescents such as performing physical activities as suggested by WHO (Word Health Organization), doing a moderate level of physical activity every day for 60 minutes or at least a high level of physical activity with a frequency of 3 times a week (22). It is also necessary to limit the intake of food groups with high sugar, according to recommendations (61), which suggests a decrease in sugar usage to below $5 \%$ or 25 grams, and the addition of sugar should not exceed $10 \%$ of the total daily energy intake.

\section{ACKNOWLEDGEMENT}

The researchers would like to thank the high school adolescents in the city of Surakarta, the Department of Education and Culture of the Education Authorities in the Region VII Branch, the principals, and teachers of the State High School of the Surakarta City who were willing to participate in the implementation of this research.

\section{REFERENCES}

1. Almasith YK, Yulia LRD, Wekadigunawan CSP. Path analysis on the psychosocial impact of obesity or overweight in adolescents in Surakarta, Central Java. Journal of Epidemiology and Public Health, 2018;3(2):105-17. https://doi.org/10.26911

2. Black RE, Victora CG, Walker SP, Bhutta ZA, Christian P, Onis MDe, Ezzati M. Maternal and child undernutrition and overweight in low-income and middle-income countries. Lancet, 2011;382:427-51. https://doi.org/10.1016/S01406736(13)60937-X 
3. Das JK, Salam RA, Thornburg KL, Prentice AM, Campisi S, Lassi ZS, et al. Nutrition in adolescents: physiology, metabolism, and nutritional needs. Ann N Y Acad Sci, 2017;1393(1):21-33. https://doi.org/10.1111/nyas.13330 PMid:28436102

4. Hardinsyah, Supariasa IDN. IImu gizi teori \& aplikasi (Nutrition theory and application). Jakarta: Buku Kedokteran ECG. 2018.

5. Yoo E. Waist-to-height ratio as a screening tool for obesity and cardiometabolic risk. Korean J Pediatr, 2016;59(11):425-31. https://doi.org/10.3345/kjp.2016.59. 11.425 PMid:27895689 PMCid:PMC5118501

6. Zhou D, Yang M, Yuan Z, Zhang D, Liang L, Wang C, et al. Waist-to-height ratio: a simple, effective and practical screening tool for childhood obesity and metabolic syndrome. Preventive Medicine, 2014;67:35-40. https:// doi.org/10.1016/j.ypmed.2014.06.025 PMid:24967955

7. WHO. (2016). Media centre obesity and overweight. Available at: http://www.who.int/mediacentre/factsheets/ fs311/en/ (Accessed 7 November 2019)

8. Balitbangkes RI. Riset Kesehatan Dasar (RISKESDAS) 2010. Jakarta: Balitbangkes RI. 2010.

9. Balitbangkes RI. Riset Kesehatan Dasar (RISKESDAS) 2013. Jakarta: Balitbangkes RI. 2013a.

10. Balitbangkes RI. Riset Kesehatan Dasar (RISKESDAS) 2018. Jakarta: Balitbangkes RI. 2018.

11. Balitbangkes RI. Riskesdas dalam angka provinsi Jawa Tengah 2013. Jakarta: Balitbangkes RI. 2013b.

12. Ogden CL, Carroll MD, Kit BK, Flegal KM. Prevalence of childhood and adult obesity in the United States, 20112012. JAMA, 2014;311(8):806-14. https://doi.org/10.1001/ jama.2014.732 PMid:24570244 PMCid:PMC4770258

13. Boyer BP, Nelson JA, Holub SC. Childhood body mass index trajectories predicting cardiovascular risk in adolescence. Journal of Adolescent Health, 2015;56(6):599-605. https://doi.org/10.1016/j.jadohealth.2015.01.006 PMid:25746172 PMCid:PMC4442729

14. Frank PW, Hanson RL, Knowler WC, Sievers ML, Bennett PH, Looker HC. Childhood obesity, other cardiovascular risk factors, and premature death. $\mathrm{N}$ Engl J Med, 2010;362(6):485-93. https://doi.org/10.1056/NEJMoa0904 130 PMid:20147714 PMCid:PMC2958822

15. Wright SM, Aronne LJ. Causes of obesity. Abdom Imaging, 2012;37(5):730-2. https://doi.org/10.1007/s00261-012-9862 -x PMid:22426851

16. Kurdanti W, Suryani I, Syamsiatun NH, Siwi LP, Adityanti MM, Mustikaningsih D, Sholihah KI. Faktor-faktor yang mempengaruhi kejadian obesitas pada remaja (Factors that influence the incidence of obesity in adolescents). Jurnal Gizi Klinik Indonesia, 2015;11(04):179-90. https://doi.org/10.22146/ijcn.22900

17. Rathi N, Riddell L, Worsley A. Food consumption patterns of adolescents aged 14 - 16 years in Kolkata, India. Nutrition Journal, 2017;16(50):1-12. https://doi.org/10.1186/s12937017-0272-3 PMid:28836982 PMCid:PMC5571590

18. Sedibe MH, Pisa PT, Feeley AB, Pedro TM, Kahn K, Norris SA. Dietary habits and eating practices and their association with overweight and obesity in rural and urban black South African adolescents. Nutrient, 2018;10(145):1-18. https://doi.org/10.3390/nu10020145 PMid:29382137 PMCid:PMC5852721
19. Fraser LK, Clarke GP, Cade JE, Edwards KL. Fast food and obesity a spatial analysis in a large United Kingdom population of children aged 13-15. Am J Prev Med, 2012;42(5):e77-e85. https://doi.org/10.1016/j.amepre.2012 .02 .007 PMid:22516506

20. Gopinath B, Flood VM, Rochtchina E, Baur LA, Chun J, Louie $Y$, et al. Carbohydrate nutrition and development of adiposity during adolescence. Obesity, 2013;21(9):1884-90. https://doi.org/10.1002/oby.20405 PMid:23519919

21. Libuda L, Alexy U, Sichert-hellert W, Stehle P, Karaolisdanckert N, Buyken AE, Kersting M. Pattern of beverage consumption and long-term association with body-weight status in German adolescents - results from the DONALD study. British Journal of Nutrition, 2008;99(6):1370-9. https://doi.org/10.1017/S0007114507862362 PMid:18034911

22. WHO. Global recommendations on physical cctivity for health 5-17 years old. 2011. Available at: https://www.who.int/dietphysicalactivity/publications/ph ysical-activity-recommendations-5-17years.pdf?ua=1 (Accessed 7 November 2019)

23. Hill JO, Wyatt HR. Role of physical activity in preventing and treating obesity. Journal of Applied Physiology, 2005;99(2):765-70. https://doi.org/10.1152/japplphysiol. 00137.2005

24. Fernandes RA, Christofaro DGD, Casonatto J, Kawaguti SS, Ronque ERV, Cardoso JR, Oliveira AR. Cross-sectional association between healthy and unhealthy food habits and leisure physical activity in adolescents. J Pediatr (Rio J), 2011;87(3):252-6. https://doi.org/10.2223/JPED.2093 PMid:21660368

25. Rahmadhaniah R, Julia M, Huriyati E. Durasi tidur, asupan energi, dan aktivitas fisik dengan kejadian obesitas pada tenaga kesehatan puskesmas (Sleep duration, energy intake, and physical activity with the incidence of obesity in puskesmas health workers). Jurnal Gizi Klinik Indonesia, 2014;11(02):85-96. https://doi.org/10.22146/ijcn.19011

26. Rennie KL. Behavioural determinants of obesity. Best Pract Clin Endocrinol Metab, 2005;19(3):343-58. https://doi.org/ 10.1016/j.beem.2005.04.003 PMid:16150379

27. Jakicic JM, Powell KE, Campbell WW, Dipietro L, Pate RR, Pescatello LS, et al. Physical activity and the prevention of weight gain in adults: a systematic review. Medicine and Science in Sports and Exercise, 2019;51(6):1262-9. https://doi.org/10.1249/MSS.0000000000001938 PMid:31095083

28. Saris WHM, Blair SN, van Baak MA, Eaton SB, Davies PSW, Pietro LDi, et al. How much physical activity is enough to prevent unhealthy weight gain? Outcome of the IASO 1st Stock Conference and consensus statement. Obs Rev, 2003;4(2):101-14. https://doi.org/10.1046/j.1467-789x.2003 .00101.x PMid:12760445

29. Ariyani NI. Strategi adaptasi orang Minang terhadap bahasa, makanan, dan norma masyarakat Jawa (Minang adaptation strategies to language, and the norms of Javanese society). Komunitas, 2013;5(17):26-37. https://doi.org/10.15294/komunitas.v5i1.2369

30. Lanfer A, Knof K, Barba G, Veidebaum T, Papoutsou S, de Henauw S, et al. Taste prefarences in association with dietary habits and weight status in European children: results from the IDEFICS study. Int J Obes, 2012;36:27-34. https://doi.org/10.1038/ijo.2011.164 PMid:21844876 
31. Deglaire A, Méjean C, Castetbon K, Kesse-Guyot E, Hercberg $\mathrm{S}$, Schlich P. Association between weight status and liking scores for sweet salt and fat according to the gender in adults (The Nutrinet-Santĕ study). Eur J Clin Nutr, 2015;69(1):40-6. https://doi.org/10.1038/ejcn.2014.139 PMid:25074389

32. Setyaningsih D, Apriyantono A, Sari MP. Analisis sensori untuk industri pangan dan argo (Sensory analysis for food and agro industries). Bogor: IPB PRESS. 2010.

33. Park DC, Yeo JH, Ryu INY, Kim SH, Jung J, Yeo SG. Differences in taste detection thresholds between normalweight and obese young adults. Acta Oto-Laryngologica, 2015;135:478-83. https://doi.org/10.3109/00016489.2014. 975370 PMid:25739740

34. Pioltine MB, de Melo ME, Santos S, Machado AD, Fernandes $A E$, Fujiwara $C T$, et al. Genetic variations in sweet taste receptor gene are related to chocolate powder and dietary fiber intake in obese children and adolescents. J Pers Med, 2018;8(7):1-9. $\quad$ https://doi.org/10.3390/jpm8010007 PMid:29382185 PMCid:PMC5872081

35. Zhang X, Zhou L, Ban X, Liu D, Jiang W, Liu X. Decreased expression of CD36 in circumvallate taste buds of high-fat diet induced obese rats. Acta Histochemica, 2011;113:6637. PMid:20926122

36. Lemeshow S, Jr DWH, Klar J, Lwanga SK. Adequacy of sample size in health studies. John Wiley \& Sons Ltd. Baffins Lane, Chichester West Sussex P019 1 UD, England. 1997.

37. Kowalski KC, Crocker PE, Donen RM. The physical cctivity questionnaire for older children (PAQ-C) and adolescents (PAQ-A) manual. Canada: University of Saskatchewan. 2004.

38. Peng M, Jaeger SR, Hautus MJ. Determining odour detection thresholds: Incorporating a methodindependent definition into the implementation of ASTM E679. Food Quality and Preference, 2012;25(2):95-104. https://doi.org/10.1016/j.foodqual.2012.02.006

39. WHO. Waist Circumference and Waist-Hip Ratio. 2008. Available at: https://apps.who.int/iris/bitstream/handle/ 10665/44583/9789241501491_eng.pdf?sequence=1 (Accessed 7 November 2019)

40. Lee O, Lee D, Lee S, Kim YS. Associations between Physical activity and obesity defined by waist-to-height ratio and body mass index in the Korean population. Plos One, 2016;11(7):1-11. https://doi.org/10.1371/journal.pone. 0158245 PMid:27447716 PMCid:PMC4957820

41. Mustelin L, Silventoinen K, Pietila, Krissanen A, Kaprio J. Physical activity reduces the influence of genetic effects on $\mathrm{BMI}$ and waist circumference: a study in young adult twins. Int J Obes (Lond), 2009;33(1):29-36. https://doi.org/ 10.1038/ijo.2008.258 PMid:19048013

42. Wiklund $P$. The role of physical activity and exercise in obesity and weight management: Time for critical appraisal. Journal of Sport and Health Science, 2016;5(2):151-4. https://doi.org/10.1016/j.jshs.2016.04.001 PMid:30356545 PMCid:PMC6188737

43. Boreham C, Robson PJ, Gallagher AM, Cran GW, Savage M, Murray LJ. Tracking of physical activity, fitness, body composition and diet from adolescence to young adulthood: The Young Hearts Project, Northern Ireland. Int J Behav Nut Phys Act, 2004;1(1):1-8. https://doi.org/ 10.1186/1479-5868-1-14 PMid:15462676 PMCid:PMC524366
44. Hills AP, Andersen LB, Byrne NM. Physical activity and obesity in children. $\mathrm{Br} \mathrm{J}$ Sports Med, 2011;45:866-70. https://doi.org/10.1136/bjsports-2011-090199 PMid:21836171

45. Healy GN, Owen N. Sedentary behaviour and biomarkers of cardiometabolic health risk in adolescents: an emerging scientific and public health issue. Rev Esp Cardiol, 2010;63(3):261-4. Available at: http://www.revespcardiol. org/

46. Ludwig DS, Pollack HA. Obesity and the economy: from crisis to opportunity. JAMA, 2015;301(5):533-5. https://doi.org/10.1001/jama.2009.52 PMid:19190318

47. Fararouei M, Brown IJ, Toori MA, Haghighi RE, Jafari J. Happiness and health behaviour in Iranian adolescent girls. J Adolesc, 2013;36(6):1187-92. https://doi.org/10.1016/ j.adolescence.2013.09.006 PMid:24215965

48. Wittberg RA, Northrup KL, Cottrell LA. Children's aerobic fitness and academic achievement: a longitudinal examination of students during their fifth and seventh grade years. American Journal of Public Health, 2012;102(12):2303-7. https://doi.org/10.2105/AJPH.2011. 300515 PMid:22698045 PMCid:PMC3519293

49. Breslin PAS. An evolutionary perspective on food and human taste. Curr Biol, 2013;23(9):1-19. https://doi.org/ 10.1016/j.cub.2013.04.010.An PMid:23660364 PMCid:PMC3680351

50. Low JYQ, Mcbride RL, Lacy KE, Keast RSJ. Psychophysical evaluation of sweetness functions across multiple sweeteners. Chem Senses, 2017;42(2):111-20. https://doi.org/10.1093/chemse/bjw109 PMid:27765786 PMCid:PMC5390504

51. Joseph PV, Reed D, Mennella JA. Individual differences among children in sucrose detection thresholds. Nursing Research, 2016;65(1):3-12. https://doi.org/10.1097/NNR. 0000000000000138 PMid:26633761 PMCid:PMC4679349

52. Ashi H, Campus G, Klingberg G, Forslund HB, Lingström P. Childhood obesity in relation to sweet taste perception and dental caries - a cross-sectional multicenter study. Food Nutr Res, 2019;63:1-7. https://doi.org/10.29219/ fnr.v63.1682 PMid:30992699 PMCid:PMC6451031

53. Wang J. Consumption of added sugars and development metabolic syndrome components among a sample of youth at risk of obesity. Applied Physiology, Nutrition, and Metabolism, 2014;39(2):512. https://doi.org/10.1139/apnm-2013-0456

54. Fayasari A, Julia M, Huriyati E. Pola makan dan indikator lemak tubuh pada remaja (Eating pattern and indicators of body fat in adolescents). Jurnal Gizi Indonesia, 2018;7(1):15-21. https://doi.org/10.14710/jgi.7.1.15-21

55. Eny KM, Wolever TMS, Corey PN, El-sohemy A. Genetic variation in TAS1R2 (Ile191Val) is associated with consumption of sugars in overweight and obese individuals in 2 distinct populations. American Journal of Clinical Nutrition, 2010;92(6):1501-10. https://doi.org/10.3945/ ajcn.2010.29836.Am PMid:20943793

56. Fushan AA, Simons CT, Slack JP, Drayna D. Association between common variation in genes encoding sweet taste signaling components and human sucrose perception. Chem Senses, 2010;35(7):579-92. https://doi.org/10.1093/ chemse/bjq063 PMid:20660057 PMCid:PMC2924427 
57. Kawai K, Sugimoto K, Nakashima K, Miura H, Ninomiya Y. Leptin as a modulator of sweet taste sensitivities in mice. Proc Natl Acad, 2000;97(20):11044-9. Available at: https://www.ncbi.nlm.nih.gov/m/pubmed/10995460/ PMid:10995460 PMCid:PMC27145

58. Umabiki M, Tsuzaki K, Kotani K, Nagai N, Sano Y, Matsuoka $Y$, et al. The improvement of sweet taste sensitivity with decrease in serum leptin levels during weight loss in obese females. Tohoku J Exp Med, 2010;220(4):267-71. https://doi.org/10.1620/tjem.220.267 PMid:20383037

59. Bartoshuk LM. Comparing sensory experiences across individuals: recent psychophysical advances illuminate genetic variation in taste perception. Chem Senses, 2000;25(4):447-60. https://doi.org/10.1093/chemse/25.4. 447 PMid:10944509
60. Pepino MY, Love-gregory L, Klein S, Abumrad NA. The fatty acid translocase gene CD36 and lingual lipase infl uence oral sensitivity to fat in obese subjects. J Lipid Res, 2012;53(3):561-6. https://doi.org/10.1194/jlr.M021873 PMid:22210925 PMCid:PMC3276480

61. WHO. Sugars intake for adults and children. 2015. Available at: http://apps.who.int/iris/bitstream/10665/149782/1/ 9789241549028_eng.pdf (Accessed 7 November 2019) 